\title{
Editorial
}

Editorial

\section{A internacionalidade da ciência}

\author{
The international nature of science
}

"A ciência, para merecer esse nome, deve ser internacional." Penso que o leitor já tenha tido conhecimento dessa assertiva. Ao menos de uma maneira. Ouvida, lida ou mesmo proclamada convictamente e aos quatro ventos. Com frequiência, a falta do pretenso caráter "internacional" leva ao demérito ou, na melhor das hipóteses, à classificação do trabalho científico como "subdesenvolvido", "de terceiro mundo", "desinteressante", "pouco competitivo", e várias outras adjetivações que apavoram nossos pesquisadores.

Mas, como dar à nossa pesquisa roupagem internacional? Para alguns, bastará redigir o manuscrito e, logicamente, publicá-lo em idioma inglês. Haja vista o pulular de novos "Brazilian Journals" e mesmo de periódicos tradicionais, assim transvestidos até na sua própria correspondência interna. Para outros, há a necessidade, que beira o fanatismo, em inserir o trabalho na imprensa estrangeira. Obviamente, é claro, do primeiro mundo. Mesmo que esta venha a ter dificuldades em encontrar relatores para determinados temas que pouco lhe dizem respeito ou lhe interessam.

Essa orientação ou, melhor dizendo, modismo atual, leva a situações que não deixam de ser risíveis. Assim, por exemplo, no último número de conceituado periódico especializado, mas do primeiro mundo, pode-se ler artigo tratando de educação populacional para o combate a vetor da dengue em prós- pera cidade do interior paulista. Por sua vez, na recente e frustrada viagem espacial, a imprensa leiga noticiou "importante pesquisa" a ser espacialmente levada a efeito por colegas nacionais sobre o mal de Chagas. Como se a medicina curativa fosse mais importante do que a preventiva. Claro está que esta não poderá propiciar os mesmos lucros que adviriam desse "Chagaspace". E que dizer das ridículas e indigestas listas dos cientistas "produtivos", baseadas nos dados do "Institute for Scientific Information", publicadas pela nossa mídia? Os exemplos são inúmeros.

E então, que fazer? Não querendo parodiar o título de famoso romance, penso que a resposta seria uma só. A internacionalidade rima com globalidade, e esta nem sempre tem esse aspecto. Ao menos na ciência. Pretender dar caráter global a tema que, pela sua natureza intrínseca, é regional, será forçar situações. Será selecionar negativamente as vocações científicas do assim chamado terceiro-mundo. Este tem muitos problemas, é verdade. Porém, as soluções terão que ser encontradas por ele mesmo. No afã de "internacionalizar" as próprias atividades de pesquisa, muitas vezes presta-se desserviço à própria população que as custeiam.

\section{Oswaldo Paulo Forattini} Editor Cientifico 